Bul. Agrohorti 4 (1) : 20 - 28 (2016)

\title{
Penetapan Umur Panen Kacang Tanah (Arachis hypogaea L.) Berdasarkan Metode Akumulasi Satuan Panas dan Kematangan Polong
}

\section{Harvesting Time Determination of Peanut (Arachis hypogaea L.) Based on Heat Unit Accumulation and Pod Development Stage}

\author{
Sasmoyo Adi Nugroho, Heni Purnamawati", dan Yudiwanti Wahyu \\ Departemen Agronomi dan Hortikultura, Fakultas Pertanian, Institut Pertanian Bogor \\ (Bogor Agricultural University), J1. Meranti, Kampus IPB Darmaga, Bogor 16680, Indonesia \\ Telp.\&Faks. 62-251-8629353 e-mail agrohort.ipb.ac.id \\ *Penulis untuk korespondensi: heni_purnama@yahoo.com
}

Disetujui 18 Januari 2016/ Published online 25 Januari 2016

\begin{abstract}
The objective of this experiment was to determine the harvesting time of three varieties of peanut (Arachis hypogaea L.) based on heat unit accumulation. The experiment was conducted at Bogor Agricultural University, Experimental Field Leuwikopo, IPB and Postharvest Laboratory Departemen of Agronomy and Horticulture IPB in March until June 2014. This experiment has two factors and three replications, varieties (as a main plot) and time harvesting (as a subsplot) which arranged by split plot design. The results revealed that three varieties, i.e., Domba, Badak, and Panther started to bloom in 24 days after planting. Badak and Panther reached their 50\% population blooming in $528.20{ }^{\circ} \mathrm{Cd}$ heat unit accumulation, 30 days after planting, while Domba reached its $50 \%$ population blooming in $562.65^{\circ} \mathrm{Cd}$ heat unit accumulation in 32 days after planting. Harvesting time Domba and Panther were $1764.2^{\circ} \mathrm{Cd}$ heat unit accumulation, in 100 days after planting, while Badak could be harvested in $1851.35^{\circ} \mathrm{Cd}$ heat unit accumulation, 105 days after planting.
\end{abstract}

Keyword: harvesting time, heat unit accumulation, peanut

\begin{abstract}
ABSTRAK
Percobaan ini bertujuan untuk menentukan umur panen tiga varietas kacang tanah (Arachis hypogea L.) berdasarkan akumulasi satuan panas. Percobaan ini dilakukan di Kebun Percobaan Leuwikopo Institut Pertanian Bogor dan Laboratorium Pascapanen Departemen Agronomi dan Hortikultura IPB pada bulan Maret hingga Juni 2014. Percobaan terdiri atas dua faktor, yaitu varietas (sebagai petak utama) dan waktu panen (sebagai anak petak) yang disusun petak terbagi (split plot) dengan tiga ulangan. Hasil penelitian menunjukkan bahwa Varietas Domba, Badak, dan Panther mulai berbunga pada 24 HST. Varietas Badak dan Panther mencapai 50\% populasi tanaman berbunga dengan akumulasi satuan panas $528.2^{\circ} \mathrm{Cd}$ pada umur panen $30 \mathrm{HST}$, sedangkan varietas Domba mencapai $50 \%$ populasi tanaman berbunga dengan akumulasi satuan panas $562.7^{\circ} \mathrm{Cd}$ pada saat 32 HST. Varietas Domba dan Panther dengan akumulasi panas $1764.2{ }^{\circ} \mathrm{Cd}$ pada umur panen $100 \mathrm{HST}$, sedangkan varietas Badak di panen pada akumulasi satuan panas $1851.4^{\circ} \mathrm{Cd}$ dengan umur panen $105 \mathrm{HST}$.
\end{abstract}

Kata kunci: akumulasi satuan panas, kacang tanah, umur panen 


\section{PENDAHULUAN}

Kacang tanah (Arachis hypogaea L.) merupakan tanaman yang mempunyai arti ekonomi cukup penting karena berperan dalam memenuhi kebutuhan pangan nasional sebagai sumber protein nabati, minyak, dan nutrisi lainnya. Adanya program pemerintah tentang diversifikasi pangan dan meningkatnya tuntutan masyarakat terhadap produk pangan berkualitas menyebabkan permintaan akan kacang tanah belum dapat terpenuhi (Deptan, 2011). Produksi kacang tanah di Indonesia yang masih tergolong rendah tidak dapat mengimbangi permintaannya yang tinggi.

Kebutuhan kacang tanah dari tahun ke tahun meningkat sekitar $4.4 \%$ sedangkan produksi kacang tanah hanya meningkat sebesar $2.5 \%$ (Widjanarko et al., 2009). Produktivitas kacang tanah di Indonesia pada tahun 2013 tergolong cukup rendah, yaitu 1.2 ton $\mathrm{ha}^{-1}$ (BPS, 2013) dibandingkan produktivitas potensial varietas unggul nasional seperti Kelinci (4.3 ton.ha ${ }^{-1}$ polong kering), Bison (3.6 ton ha ${ }^{-1}$ polong kering), Domba (4.2 ton ha ${ }^{-1}$ polong kering), atau Panther (5.4 ton ha $^{-1}$ polong kering) (Balitkabi, 2013).

Penentuan waktu panen kacang tanah di Indonesia masih menggunakan satuan waktu (hari) yang ada pada deskripsi varietas (Marzuki, 2009), sehingga akan dapat terjadi perbedaan kematangan polong pada waktu yang sama jika tanaman ditanam pada lokasi dengan ketinggian yang berbeda. Perbedaan tersebut terjadi karena perbedaan suhu harian yang diterima di tiap lokasi tertentu. Selain itu, kebanyakan petani di Indonesia menggunakan indikator penyakit bercak daun sebagai indikator waktu panen kacang tanah. Namun saat ini, varietas kacang tanah yang tahan penyakit bercak daun telah dikembangkan (Yudiwanti et al., 2008), sehingga penentuan waktu panen tidak dapat lagi menggunakan indikator tersebut.

Penentuan waktu panen juga dapat dilakukan dengan metode satuan panas. Metode satuan panas adalah metode kuantitatif mengenai hubungan antara suhu dan tanaman. Penggunaan metode ini didasari pemikiran bahwa suhu dipandang sebagai suatu faktor yang mewakili tersedianya energi guna pertumbuhan dan perkembangan tanaman. Metode ini populer dengan istilah degree-days, heat unit, dan growing degree-days (Wang, 1960).

Kelebihan dari penerapan satuan panas sebagai umur pertumbuhan dan panen kacang tanah yaitu dapat mempermudah peramalan produksi dengan metode "energy-crop-growth", simulasi produksi, dan komputerisasi. Diharapkan dengan penggunaan metode akumulasi satuan panas dalam menentukan umur panen kacang tanah dapat meningkatkan keakuratan dalam menentukan waktu panen, memudahkan taksasi hasil atau simulasi produksi dan komputerisasi.

Hasil penelitian sebelumnya yakni kacang tanah tipe Valencia, didapat varietas Kelinci mulai berbunga pada $403.60{ }^{\circ} \mathrm{Cd}$ (suhu dasar $10{ }^{\circ} \mathrm{C}$ ) atau $334.60{ }^{\circ} \mathrm{Cd}$ (suhu dasar $13{ }^{\circ} \mathrm{C}$ ), sedangkan varietas Gajah dan Jerapah keduanya mulai berbunga pada $420.75{ }^{\circ} \mathrm{Cd}$ atau $348.75{ }^{\circ} \mathrm{Cd}$. Varietas Kelinci mencapai $50 \%$ tanaman tanaman berbunga pada $453.85{ }^{\circ} \mathrm{Cd}$ atau $376.85{ }^{\circ} \mathrm{Cd}$, sedangkan varietas Gajah dan Jerapah mencapai $50 \%$ tanaman berbunga pada $470.95{ }^{\circ} \mathrm{Cd}$ atau $391.80{ }^{\circ} \mathrm{Cd}$. Varietas Kelinci dan Jerapah dapat dipanen pada $1619.35{ }^{\circ} \mathrm{Cd}$ (suhu dasar $10{ }^{\circ} \mathrm{C}$ ) atau $1346.35{ }^{\circ} \mathrm{Cd}$ (suhu dasar $13{ }^{\circ} \mathrm{C}$ ), sedangkan varietas Gajah dapat dipanen pada $1792.50{ }^{\circ} \mathrm{Cd}$ atau $1489.50{ }^{\circ} \mathrm{Cd}$ (Santoso, 2013).

Penelitian ini bertujuan menentukan umur panen tiga varietas kacang tanah berdasarkan akumulasi satuan panas.

\section{BAHAN DAN METODE}

Penelitian ini dilaksanakan pada 6 Maret hingga 24 Juni 2014 di Kebun Percobaan Leuwikopo (koordinat $6.565206{ }^{0} \mathrm{LS}$ dan $106.725557{ }^{0} \mathrm{BT}$, ketinggian $\pm 210 \mathrm{~m} \mathrm{dpl}$ ) dan Laboratorium Pascapanen (Postharvest Laboratory), Departemen Agronomi dan Hortikultura, Institut Pertanian Bogor.

Bahan yang digunakan dalam penelitian ini antara lain benih tiga varietas kacang tanah (Domba, Badak, dan Panther), Dolomit, pupuk kandang, pupuk NPK Phonska (15-15-15), insektisida dan fungisida (Furadan, Curacron, dan Antracol). Alat yang digunakan antara lain alatalat pertanian, penggaris, timbangan digital, jangka sorong digital, kamera digital, dan latar foto.

Percobaan terdiri atas dua faktor yang disusun petak terbagi (split plot) dalam rancangan kelompok lengkap teracak (RKLT) dengan tiga ulangan. Petak utama varietas dengan tiga taraf, yaitu Domba (V1), Badak (V2), Panther (V3). Sebagai anak petak yaitu waktu panen dengan tujuh taraf yaitu $80(\mathrm{P} 1), 85(\mathrm{P} 2), 90(\mathrm{P} 3), 95$ (P4), 100 (P5), 105 (P6), dan 110 hari (P7).

Benih didapatkan dari Balai Besar Bioteknologi dan Genetika (BB BIOGEN) Bogor dan Seed Center Departemen Agronomi dan Hortikultura. Seleksi benih dilakukan dengan memilih benih yang seragam dalam ukuran dan bentuk. Pupuk kandang dan Dolomit dengan dosis 1 ton ha ${ }^{-1}$ dan $600 \mathrm{~kg} \mathrm{ha}^{-1}$ ditambahkan bersamaan 
dengan pengolahan tanah. Jarak tanam yang digunakan $40 \mathrm{~cm} \times 20 \mathrm{~cm}$ dengan penanaman satu benih per lubang tanam. Pemeliharaan yang dilakukan meliputi penyulaman, penyiangan, penyiraman, pembumbunan, dan pengendalian organisme pengganggu tanaman.

Pemeliharaan yang dilakukan meliputi penyulaman, pemberian tanda pada tanaman sulaman dan tanaman sakit, pembumbunan, penyiraman, penyiangan, dan pengendalian organisme pengganggu tanaman. Pemberian tanda bertujuan menandai tanaman sulaman agar tidak digunakan sebagai sampel karena sampel yang diambil harus memiliki umur yang sama pada tiap panen. Panen dilakukan sesuai dengan perlakuan waktu panen.

Pengamatan dilakukan pada sebelum dan sesudah panen. Peubah yang diamati adalah peubah kuantitatif dan kualitatif. Pengamatan yang diamati dilakukan pada 6 tanaman contoh disetiap ulangan pada setiap varietas. Deskripsi pertumbuhan kacang tanah disajikan pada tabel 1 .

Tabel 1. Perbedaan antar stadium kematangan polong kacang tanah

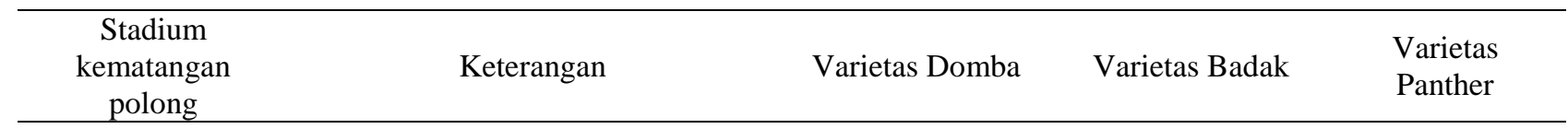

Fase awal pembentukan polong, bentuk polong belum sempurna, diameter polong dua kali diameter ginofor atau tangkai polong, Cipo sebagian isi masih berupa bahan cair, jaring-jaring belum terlihat, serta polong muda yang panjangnya kurang dari $3 \mathrm{~cm}$
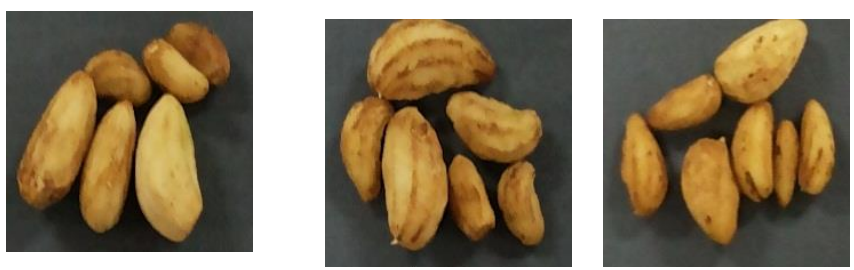

Bentuk polong sempurna, ukuran polong belum maksimal, pengisian masih berlangsung, kulit polong

Setengah penuh bagian luar masih kuning, sebagian jaring-jaring sudah terlihat
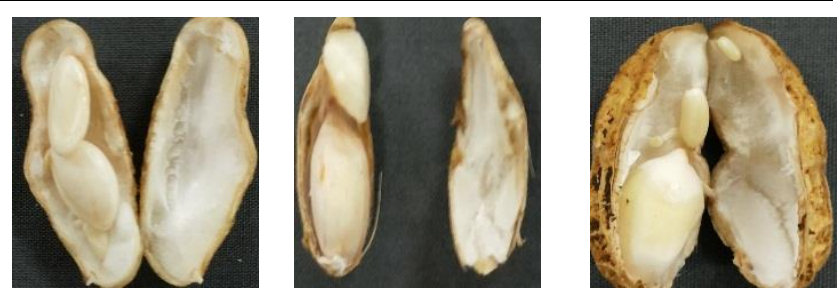

Bentuk polong sempurna, ukuran polong maksimal, kulit polong bagian luar berwarna kuning

Penuh 1 kecoklatan, jaring-jaring sudah terlihat, kulit polong bagian dalam bewarna putih, kulit biji berwarna putih
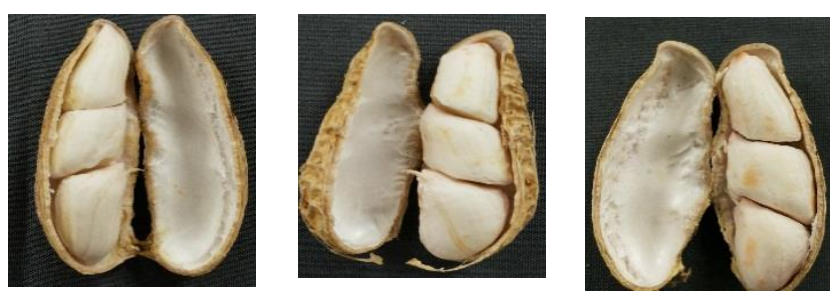

\begin{abstract}
Bentuk polong sempurna, ukuran polong maksimal, kulit polong bagian luar berwarna coklat, jarring-jaring sudah terlihat, kulit polong bagian dalam sudah terdapat bercak coklat, warna biji merah muda (soft pink)
\end{abstract}

Penuh 2
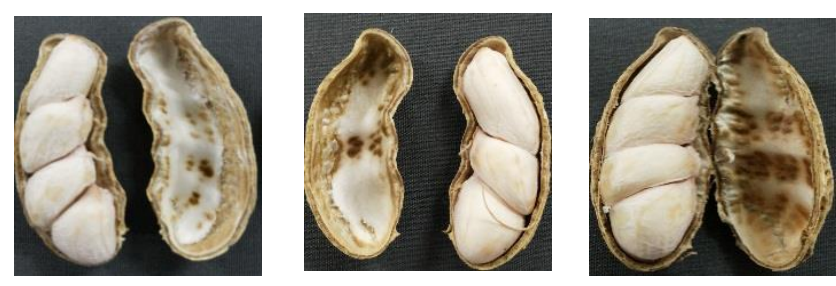

Bentuk polong sempurna, ukuran polong maksimal, kulit polong bagian luar berwarna coklat,

Penuh 3 jaring-jaring terlihat, kulit polong bagian dalam terdapat bercak coklat, kulit biji berwarna coklat muda
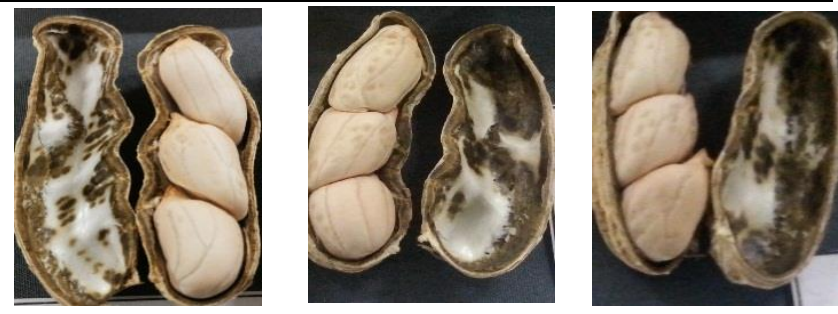
Rusak

Biji rusak terserang hama dan penyakit
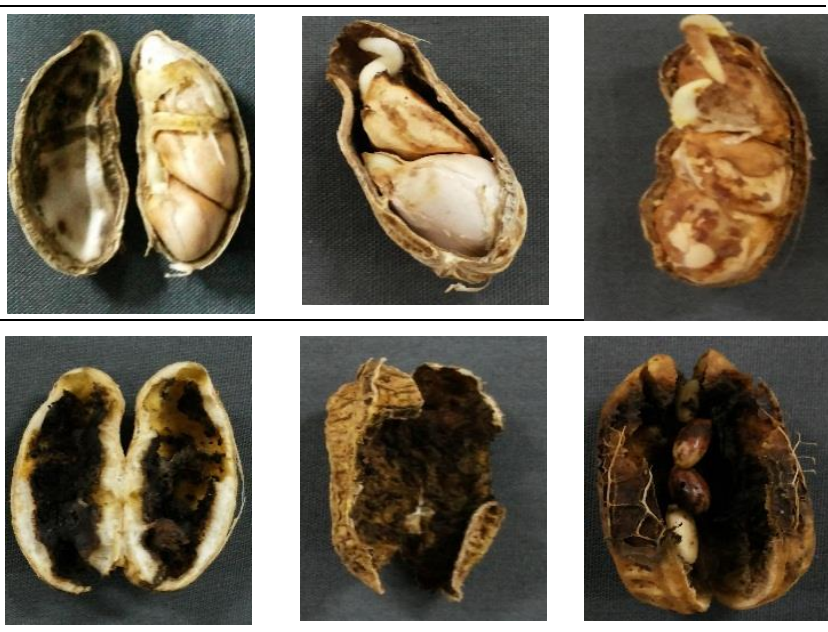

Parameter pengamatan meliputi umur berbunga, tinggi tanaman pada saat panen, dan akumulasi satuan panas. Hasil perhitungan diperoleh dengan menggunakan persamaan sebagai berikut :

$$
S P_{n}=\sum_{i=1}^{n}\left(\frac{t_{\text {maks }}+t_{\min }}{2}\right)-t_{b}
$$

Keterangan:

$S P_{n} \quad$ : akumulasi panas sampai hari ke- $n\left({ }^{0} \mathrm{Cd}\right)$

$t_{\text {maks }} \quad:$ suhu maksimum harian $\left({ }^{0} \mathrm{C}\right)$

$t_{\min } \quad:$ suhu minimum harian $\left({ }^{0} \mathrm{C}\right)$

$t_{\mathrm{b}} \quad:$ suhu dasar $\left({ }^{0} \mathrm{C}\right)$

$i \quad$ : hari setelah tanam

$n \quad$ : hari pada fase tertentu

Jumlah polong total, jumlah polong total dihitung seluruh polong hampa dan polong isi. Selain itu, perhitungan perbandingan polong isi terhadap keseluruhan polong per tanaman juga dilakukan. Bobot polong, bobot polong per tanaman contoh diukur dengan menggunakan timbangan analitik tanpa polong cipo. Indeks masak biji kulit dengan menghitung perbandingan bobot biji dengan bobot kulit tanaman.

Data yang diperoleh dianalisis dengan menggunakan Uji-F. Uji lanjut yang dilakukan menggunakan uji lanjut Beda Nyata Jujur (BNJ) apabila hasil interaksi pada Uji-F tidak berpengaruh nyata maka dilanjutkan dengan pengujian faktor tunggal umur panen pada setiap varietas.

\section{HASIL DAN PEMBAHASAN}

\section{Kondisi Umum}

Jenis tanah di lokasi percobaan termasuk jenis tanah latosol dengan $\mathrm{pH}$ rendah (masam) yaitu 6.0, sehingga dilakukan penambahan dolomit $\mathrm{CaMg}\left(\mathrm{CO}_{3}\right)_{2}$ dengan dosis $600 \mathrm{~kg} \mathrm{ha}^{-1}$ saat pengolahan tanah diharapkan dapat memperbaiki sifat kimia tanah, yaitu meningkatkan $\mathrm{pH}$, meningkatkan kandungan $\mathrm{Ca}$ dan $\mathrm{Mg}$, serta meningkatkan ketersediaan unsur $\mathrm{P}$ dalam tanah. Selain itu, dengan kandungan kalsium mempengaruhi pembentukan polong dan pengisian biji (Purwono dan Purnamawati, 2007).

Berdasarkan data iklim dan cuaca harian dari stasiun BMKG Dramaga, curah hujan selama penanaman antara lain bulan Maret $238.8 \mathrm{~mm}$ bulan $^{-1}$, April $510.9 \mathrm{~mm}$ bulan $^{-1}$, Mei $296.4 \mathrm{~mm}$ bulan $^{-1}$, Juni $34.4 \mathrm{~mm}$ bulan $^{-1}$. Rata-rata suhu minimum selama penanaman adalah $23.03{ }^{\circ} \mathrm{C}$ dan suhu maksimum adalah $31.93{ }^{\circ} \mathrm{C}$. Rata-rata hari hujan 19 hari/bulan, RH $85 \%$, dan rata-rata intensitas radiasi matahari $303.5\left(\mathrm{cal} \mathrm{cm} \mathrm{cm}^{-2}\right.$ ).

Daya tumbuh benih tinggi $(>80 \%)$ antara lain varietas Domba 91.90\%, varietas Badak 90.95\%, dan $90.48 \%$ untuk varietas Panther. Pertumbuhan awal tanaman di lapangan menunjukan hasil yang baik. Pada 3 minggu setelah tanam (MST), terdapat tanaman yang terkena Peanut stripe virus (PStV) yang menyebabkan penyakit belang. Penyebab virus tersebut diakibatkan terbawa genetik dari benih yang digunakan. Untuk mencegah lebih meluasnya virus tersebut, penyemprotan insektisida dilakukan sebagai cara pengendalian vektor virus tersebut. Selain itu, tanaman juga terserang penyakit layu bakteri (Pseudomonas solanacearum) dan bercak daun (Cercospora sp.).

Hama yang menyerang selama penanaman antara lain belalang (Oxya $s p$.), kutu daun (Aphis glycine), rayap (Odontotermes spp.), ulat polong (Ettiella zinckenella), kepik penghisap pucuk (Anoplocnemis phasiana). Untuk memperkecil tingkat serangan hama, penyemprotan insektisida berbahan aktif Profenofos dan fungisida berbahan aktif Propineb dilakukan sebanyak 2 kali yaitu pada 5 MST dan 
7 MST. Gulma yang tumbuh di sekitar tanaman antara lain Mimosa pudica, Amaranthus dubius, Hedyotis corimbosa, Axonopus compressus, Eleusin indica. Penyiangan dilakukan pada 2 MST dan 4 MST, gulma besar dipotong menggunakan gunting agar proses pembentukan polong tidak terganggu.

\section{Umur Berbunga}

Penentuan umur berbunga kacang tanah didasarkan pada persentase tanaman berbunga dalam populasi. Pengamatan umur berbunga dilakukan sejak ada tanaman dalam populasi mulai berbunga hingga lebih dari $50 \%$ populasi telah berbunga. Beberapa tanaman dari varietas Badak, Domba, dan Panther mulai berbunga pada waktu yang sama yaitu 24 hari setelah tanam (HST). Varietas Badak dan panther mencapai $50 \%$ populasi tanaman berbunga saat 30 HST, sedangkan varietas Domba mencapai 50\% populasi tanaman berbunga saat $32 \mathrm{HST}$. Hal ini sesuai dengan pernyataan Pitojo (2005) yang menyatakan bunga kacang tanah mulai muncul dari ketiak daun pada bagian bawah tanaman yang berumur antara 28-35 hari. Pembentukan bunga tetap berlangsung saat tanaman memasuki fase pengisian biji. Selisih antara periode waktu berbunga dengan waktu panen menggambarkan periode pengisian biji (Purnamawati, 2012).

Varietas Badak dan Panther mencapai $50 \%$ tanaman berbunga pada $528.2{ }^{0} \mathrm{Cd}$, sedangkan varietas Domba mencapai 50\% tanaman berbunga pada $562.7{ }^{\circ} \mathrm{Cd}$. Penghitungan satuan panas adalah dengan menghitung rata-rata suhu maksimum dan minimum harian lalu dikurangi dengan suhu dasar tanaman (Ketring dan Reid, 1995). Penghitungan satuan panas terbaik adalah jika suhu dasar yang digunakan adalah suhu dasar tanaman pada fase vegetatif (Kuntyastuti, 1993). Suhu dasar pada fase vegetatif tanaman kacang tanah menurut Leong dan Ong (1983) adalah $10^{\circ} \mathrm{C}$.

Suhu udara berpengaruh pula terhadap masalah pembungaan. Suhu untuk pertumbuhan optimum berkisar antara $27{ }^{0} \mathrm{C}$ dan $30{ }^{\circ} \mathrm{C}$ tergantung pada masing-masing varietas (Adisarwanto et al., 1993). Hal ini sama dengan data suhu rata-rata minimum maksimum harian yang berkisar antara $27{ }^{\circ} \mathrm{C}$ dan $28{ }^{\circ} \mathrm{C}$ (Tabel 2).

Tabel 2. Konversi satuan hari ke satuan panas saat kacang tanah berbunga

\begin{tabular}{|c|c|c|c|}
\hline \multirow[b]{2}{*}{ Umur Tanaman (HST) } & \multirow[b]{2}{*}{$\begin{array}{l}\text { Suhu Rata-rata minimum } \\
\text { maksimum }\left({ }^{0} \mathrm{C}\right)\end{array}$} & \multicolumn{2}{|c|}{ Suhu Dasar $10^{\circ} \mathrm{C}$} \\
\hline & & Satuan Panas $\left({ }^{0} \mathrm{C}\right)$ & $\begin{array}{c}\text { Akumulasi Satuan Panas } \\
\left({ }^{0} \mathrm{Cd}\right)^{\mathrm{a}}\end{array}$ \\
\hline 1 & 27.0 & 17.0 & 33.7 \\
\hline$\ldots$ & $\ldots$ & $\ldots$ & $\ldots$ \\
\hline 24 & 27.2 & 17.2 & 420.8 \\
\hline 26 & 27.5 & 17.5 & 456.3 \\
\hline 28 & 28.0 & 18.0 & 492.0 \\
\hline 30 & 28.2 & 18.2 & 528.2 \\
\hline 32 & 27.2 & 17.2 & 562.7 \\
\hline
\end{tabular}

Keterangan: ${ }^{a}$ degrees celcius day

\section{Rekapitulasi Sidik Ragam}

Parameter yang digunakan dalam penelitian ini meliputi tinggi tanaman, jumlah polong, bobot polong, bobot biji, bobot kulit, dan indeks masak biji kulit. Hasil dari analisis ragam (Tabel 3) menunjukan bahwa varietas berpengaruh nyata terhadap tiga parameter pengamatan antara lain tinggi tanaman, bobot kulit, dan indeks masak biji kulit. Umur panen berpengaruh sangat nyata terhadap semua parameter kecuali bobot kulit. Interaksi antara varietas dan umur panen tidak berpengaruh terhadap semua parameter kecuali indeks masak biji kulit. Untuk melihat pengaruh umur panen pada setiap varietas yang diuji (Badak, Domba, dan Panther) maka dilakukan pengujian dengan faktor tunggal (umur panen). Pengujian dilakukan terhadap beberapa parameter di antaranya tinggi tanaman, bobot polong, bobot biji, dan indeks masak biji kulit.

Parameter yang juga digunakan untuk menentukan panen terbaik adalah kematangan polong atau stadium kematangan polong. Parameter tersebut meliputi stadium polong penuh 3 , penuh 2 , penuh 1 , setengah penuh, cipo, berkecambah, dan rusak (Tabel 1). Hasil analisis sidik ragam (Tabel 4) yang disajikan menunjukan bahwa varietas tidak berpengaruh nyata terhadap stadium kematangan polong kecuali cipo, penuh 1 dan penuh 3. Umur panen berpengaruh sangat nyata terhadap semua stadium kematangan kecuali pada stadium polong rusak. Interaksi antara varietas dan umur panen tidak berpengaruh 
pada semua stadium polong kecuali stadium

polong penuh 3 .

Tabel 3. Rekapitulasi hasil sidik ragam karakter kuantitatif pengaruh varietas, umur panen dan interaksi keduanya pada tanaman kacang $\operatorname{tanah}^{\mathrm{a}}$

\begin{tabular}{lcccc}
\hline \multicolumn{1}{c}{ Parameter } & \multicolumn{3}{c}{ F-Hitung } & \multirow{2}{*}{ KK $(\%)$} \\
\cline { 2 - 4 } & Varietas & Umur Panen & Interaksi & 4.57 \\
Tinggi Tanaman & $0.0005 * *$ & $<.0001 * *$ & $0.6973 \mathrm{tn}$ & 18.97 \\
Jumlah Polong & $0.1275 \mathrm{tn}$ & $0.0008 * *$ & $0.7521 \mathrm{tn}$ & 21.73 \\
Bobot kulit & $0.0049 * *$ & $0.0138^{*}$ & $0.8116 \mathrm{tn}$ & 17.47 \\
Bobot biji & $0.1456 \mathrm{tn}$ & $<.0001 * *$ & $0.7877 \mathrm{tn}$ & 17.79 \\
Bobot Polong & $0.0679 \mathrm{tn}$ & $0.0002 * *$ & $0.8005 \mathrm{tn}$ & 10.16 \\
Indeks Masak Biji Kulit & $0.0002 * *$ & $<.0001 * *$ & $0.0185 *$ & \\
\hline Keterangan: ${ }^{2 * *}$ sangat nyata $(\mathrm{F}$ hitung $<1 \%),{ }^{*}$ Nyata $(1 \%<$ F hitung <5\%), tn Tidak nyata $($ F hitung $>5 \%)$ &
\end{tabular}

Tabel 4. Rekapitulasi hasil sidik ragam stadium kematangan pengaruh varietas, umur panen dan interaksi keduanya pada tanaman kacang $\operatorname{tanah}^{\mathrm{a}}$

\begin{tabular}{lcccc}
\hline \multirow{2}{*}{ Stadium Kematangan Polong } & \multicolumn{3}{c}{ F-hitung } & \multirow{2}{*}{ KK (\%) } \\
\cline { 2 - 4 } & Varietas & Umur Panen & Interaksi & $6.83 \mathrm{a}$ \\
Penuh 3 & $0.0407 *$ & $<.0001 * *$ & $0.0170 *$ & 15.53 \\
Penuh 2 & $0.2693 \mathrm{tn}$ & $<.0001 * *$ & $0.1692 \mathrm{tn}$ & 23.2 \\
Penuh 1 & $0.0020^{* *}$ & $<.0001 * *$ & $0.3045 \mathrm{tn}$ & $7.22 \mathrm{a}$ \\
Setengah penuh & $0.4072 \mathrm{tn}$ & $0.0007 * *$ & $0.6180 \mathrm{tn}$ & 12.91 \\
Cipo & $<.0001 * *$ & $0.0002 * *$ & $0.6668 \mathrm{tn}$ & $6.42 \mathrm{a}$ \\
Berkecambah & $0.1707 \mathrm{tn}$ & $0.0121 *$ & $0.7409 \mathrm{tn}$ & $16.14 \mathrm{a}$ \\
Rusak & $0.4753 \mathrm{tn}$ & $0.2885 \mathrm{tn}$ & $0.3073 \mathrm{tn}$ & \\
\hline
\end{tabular}

Keteragan: ${ }^{a}$ Angka yang di ikuti huruf a merupakan hasil analisis setelah dilakukan transformasi data dengan arcsin akar kuadrat,** sangat nyata $(\mathrm{F}$ hitung $<1 \%)$, * Nyata $(5 \%<\mathrm{F}$ hitung $<1 \%)$, tn Tidak nyata $(\mathrm{F}$ hitung $>5 \%)$

\section{Umur Panen}

Pengamatan umur panen dilakukan pada tujuh taraf waktu pemanenan, yaitu 80,85, 90, 95, 100, 105, dan 110 HST. Berdasarkan hasil konversi satuan hari ke satuan panas (Tabel 5), panen dilakukan pada saat akumulasi satuan panas tanaman berkisar antara $1408.2^{\circ} \mathrm{Cd}$ dan 1940.5 ${ }^{0} \mathrm{Cd}$ (pada suhu dasar $10{ }^{\circ} \mathrm{C}$ ). Suhu rata-rata minimum dan maksimum pada saat tujuh taraf waktu panen tergolong optimum untuk pertumbuhan.

Umur panen kacang tanah ditentukan berdasarkan tingkat kematangan polong yang mencapai standar konsumsi tertinggi. Stadium penuh dua dalam penelitian dibutuhkan sebagai tingkat kematangan standar konsumsi (Tabel 6).

Tabel 5. Konversi satuan hari ke satuan panas pada umur panen kacang tanah

\begin{tabular}{|c|c|c|c|}
\hline \multirow{2}{*}{ Umur tanaman (HST) } & \multirow{2}{*}{$\begin{array}{c}\text { Suhu rata-rata minimum } \\
\text { maksimum }\left({ }^{\circ} \mathrm{C}\right)\end{array}$} & \multicolumn{2}{|c|}{ Suhu Dasar $10{ }^{\circ} \mathrm{C}$} \\
\hline & & Satuan panas $\left({ }^{\circ} \mathrm{C}\right)$ & Akumulasi satuan panas $\left({ }^{\circ} \mathrm{Cd}\right)^{\mathrm{a}}$ \\
\hline 80 & 27.3 & 17.3 & 1408.2 \\
\hline 85 & 27.6 & 17.6 & 1496.7 \\
\hline 90 & 27.9 & 17.9 & 1583.9 \\
\hline 95 & 27.7 & 17.7 & 1673.1 \\
\hline 100 & 28.3 & 18.3 & 1764.2 \\
\hline 105 & 26.5 & 16.5 & 1851.4 \\
\hline 110 & 27.8 & 17.8 & 1940.5 \\
\hline
\end{tabular}

Keterangan: ${ }^{\mathrm{a}}$ degrees celcius day

Hal ini karena penanganan panen membutuhkan waktu yang cukup lama. Persentase polong penuh dua tertinggi dan terendah pada varietas Domba yaitu saat umur panen 95 HST dan 110 HST. Varietas Badak memiliki persentase stadium penuh dua tertinggi dan terendah pada umur panen 90 HST dan 110 HST. Persentase stadium penuh dua tertinggi dan terendah varietas Panther saat umur panen 85 HST dan 110 HST.
Hasil dari ketiga varietas menunjukan perbedaan pada persentase tertinggi, sedangkan persentase terendah menunjukan pada umur panen yang sama, hal tersebut karena pada 110 HST sudah terbentuk stadium polong baru yaitu stadium polong 3 .

Selain dengan tingkat kematangan polong, penentuan umur panen kacang tanah juga dengan bobot polong per tanaman (Tabel 7). Bobot 
polong per tanaman pada varietas Domba dan Panther terbesar dan terkecil yaitu pada umur panen 100 HST dan 80 HST. Varietas Badak mencapai bobot polong per tanaman terbesar dan terkecil pada saat umur 105 HST dan 80 HST.
Tingkat kematangan polong tidak dapat menjadi faktor tunggal penentuan umur kacang tanah karena pada saat persentase penuh dua mencapai tertinggi tidak diikuti dengan bobot polong per tanaman yang besar.

Tabel 6. Persentase polong stadium penuh 2 antar varietas tanpa menyertakan polong cipo tanaman kacang tanah

\begin{tabular}{|c|c|c|c|c|c|c|c|}
\hline \multirow{2}{*}{ Varietas } & \multicolumn{7}{|c|}{ Umur Panen (HST) } \\
\hline & 80 & 85 & 90 & 95 & 100 & 105 & 110 \\
\hline & \multicolumn{7}{|c|}{----- $\left(\%^{\mathrm{a}}\right)-$} \\
\hline Domba & $40.773 \mathrm{bc}$ & $56.010 \mathrm{a}$ & $55.903 \mathrm{a}$ & $60.437 \mathrm{a}$ & $58.027 \mathrm{a}$ & $53.360 \mathrm{ab}$ & $29.900 \mathrm{c}$ \\
\hline Badak & $60.197 a$ & $49.817 \mathrm{ab}$ & $63.030 \mathrm{a}$ & $58.513 a$ & $59.777 \mathrm{a}$ & $56.757 \mathrm{ab}$ & $37.537 \mathrm{~b}$ \\
\hline Panther & $53.430 \mathrm{ab}$ & $66.203 \mathrm{a}$ & $61.293 \mathrm{ab}$ & $57.657 \mathrm{ab}$ & $58.100 \mathrm{ab}$ & $57.503 \mathrm{ab}$ & $35.483 b$ \\
\hline
\end{tabular}

Tabel 7. Nilai tengah bobot polong tanpa polong cipo tiga varietas kacang tanah pada tujuh umur panen

\begin{tabular}{cccccccc}
\hline \multirow{2}{*}{ Varietas } & \multicolumn{7}{c}{ Umur Panen (HST) } \\
\cline { 2 - 8 } & 80 & 85 & 90 & 95 & 100 & 105 & 110 \\
\hline & & & $---------\left(\mathrm{g}^{\mathrm{a}}\right)---------$ & & \\
Domba & $35.987 \mathrm{a}$ & $42.617 \mathrm{a}$ & $41.563 \mathrm{a}$ & $40.757 \mathrm{a}$ & $55.937 \mathrm{a}$ & $48.873 \mathrm{a}$ & $39.933 \mathrm{a}$ \\
Badak & $31.000 \mathrm{~b}$ & $36.163 \mathrm{ab}$ & $36.267 \mathrm{ab}$ & $47.793 \mathrm{ab}$ & $46.840 \mathrm{ab}$ & $50.000 \mathrm{a}$ & $44.200 \mathrm{ab}$ \\
Panther & $28 . \mathrm{a} 920$ & $33.463 \mathrm{a}$ & $39.110 \mathrm{a}$ & $39.247 \mathrm{a}$ & $47.607 \mathrm{a}$ & $41.283 \mathrm{a}$ & $38.377 \mathrm{a}$ \\
\hline
\end{tabular}

Keterangan: ${ }^{a}$ Angka yang diikuti huruf sama pada baris yang sama menunjukkan hasil yang tidak berbeda nyata menurut uji BNJ dengan $\alpha=5 \%$

Bobot biji merupakan salah satu faktor penentu umur panen kacang tanah (Tabel 8). Hasil bobot biji terbesar dan terkecil masing-masing varietas tidak berbeda dengan bobot polong. Varietas Badak memiliki bobot biji terbesar dan terkecil saat umur panen 110 HST dan 85 HST.
Bobot biji varietas Domba dan Panther terbesar dan terkecil pada umur panen 100 HST dan 80 HST. Bobot polong dan biji menjadi salah satu faktor penentu umur panen karena kedua peubah ini menentukan nilai ekonomi kacang tanah.

Tabel 8. Nilai tengah bobot biji tiga varietas kacang tanah pada tujuh umur panen

\begin{tabular}{cccccccc}
\hline \multirow{2}{*}{ Varietas } & \multicolumn{7}{c}{ Umur Panen (HST) } \\
\cline { 2 - 8 }$y$ & 80 & 85 & 90 & 95 & 100 & 105 & 110 \\
\hline \multirow{2}{*}{ Domba } & $24.200 \mathrm{~b}$ & $28.147 \mathrm{ab}$ & $29.523 \mathrm{ab}$ & $29.163 \mathrm{ab}$ & $40.347 \mathrm{a}$ & $34.960 \mathrm{ab}$ & $28.783 \mathrm{ab}$ \\
Badak & $21.470 \mathrm{~b}$ & $25.673 \mathrm{ab}$ & $27.250 \mathrm{ab}$ & $35.657 \mathrm{a}$ & $34.283 \mathrm{ab}$ & $36.867 \mathrm{a}$ & $34.68 \mathrm{ab}$ \\
Panther & $19.727 \mathrm{a}$ & $23.690 \mathrm{a}$ & $27.613 \mathrm{a}$ & $29.630 \mathrm{a}$ & $33.947 \mathrm{a}$ & $30.527 \mathrm{a}$ & $30.050 \mathrm{a}$ \\
\hline
\end{tabular}

Keterangan: ${ }^{a}$ Angka yang diikuti huruf sama pada baris yang sama menunjukkan hasil yang tidak berbeda nyata menurut uji BNJ dengan $\alpha=5 \%$

Umur panen kacang tanah juga ditentukan berdasarkan indeks masak biji kulit (Tabel 9). Indeks masak biji kulit merupakan perbandingan bobot biji dengan bobot kulit. Semakin besar nilai indeks masak biji kulit menunjukan semakin dominan perbandingan bobot biji terhadap bobot kulit. Varietas Domba memiliki indeks masak biji kulit terbesar dan terkecil saat 100 HST dan 85 HST. Untuk varietas Badak dan Panther memiliki indeks masak biji kulit terbesar dan terkecil yang sama yaitu pada 110 HST dan 80 HST.

Umur panen kacang tanah ditentukan berdasarkan tingkat kematangan polong, bobot polong, bobot biji, dan indeks masak biji kulit
(Tabel 6, 7, 8, dan 9). Umur panen masing-masing varietas adalah 100 HST dengan akumulasi satuan panas sebesar $1764.2^{\circ} \mathrm{Cd}$ pada varietas Domba dan Panther, sedangkan varietas Badak memiliki umur 105 HST dengan akumulasi satuan panas sebesar $1851.35{ }^{\circ} \mathrm{Cd}$.

Umur panen yang didapatkan berbeda dengan deskripsi varietas tanaman kacang tanah yang tercantum dalam pedoman teknis pengelolaan produksi kacang tanah, kacang hijau, dan aneka kacang (Direktorat Jenderal Tanaman Pangan, 2013). Umur panen pada deskripsi varietas adalah 90-95 HST untuk varietas Domba dan Panther, sedangkan varietas Badak 95 HST. 
Tabel 9. Nilai tengah indeks masak biji kulit tiga varietas kacang tanah pada tujuh umur panen

\begin{tabular}{cccccccc}
\hline \multirow{2}{*}{ Varietas } & \multicolumn{7}{c}{ Umur Panen (HST) } \\
\cline { 2 - 7 } & 80 & 85 & 90 & 95 & 100 & 105 & 110 \\
\hline Domba & $2.4567 \mathrm{a}$ & $2.1200 \mathrm{a}$ & $2.5567 \mathrm{a}$ & $2.6800 \mathrm{a}$ & $2.7767 \mathrm{a}$ & $2.6467 \mathrm{a}$ & $2.7200 \mathrm{a}$ \\
Badak & $2.4433 \mathrm{c}$ & $2.5667 \mathrm{c}$ & $3.4467 \mathrm{ab}$ & $3.0400 \mathrm{abc}$ & $2.7800 \mathrm{bc}$ & $2.8700 \mathrm{bc}$ & $3.6967 \mathrm{a}$ \\
Panther & $2.2300 \mathrm{c}$ & $2.6100 \mathrm{bc}$ & $2.6500 \mathrm{bc}$ & $3.1767 \mathrm{ab}$ & $2.6167 \mathrm{bc}$ & $2.9200 \mathrm{abc}$ & $3.5267 \mathrm{a}$ \\
\hline Keterangan: ${ }^{2}$ Angka yang diikuti huruf sama pada baris yang sama menunjukkan hasil yang tidak berbeda nyata menurut uji BNJ \\
dengan $\alpha=5 \%$
\end{tabular}

\section{KESIMPULAN}

Varietas Domba, Badak, dan Panther mulai berbunga pada 24 HST. Varietas Badak dan Panther mencapai $50 \%$ populasi tanaman berbunga dengan akumulasi satuan panas 528.2 ${ }^{0} \mathrm{Cd}$ pada umur panen $30 \mathrm{HST}$, sedangkan varietas Domba mencapai $50 \%$ populasi tanaman berbunga dengan akumulasi satuan panas 562.7 ${ }^{0} \mathrm{Cd}$ pada saat 32 HST.Varietas Domba dan Panther dengan akumulasi panas $1764.2{ }^{\circ} \mathrm{Cd}$ pada umur panen $100 \mathrm{HST}$, sedangkan varietas Badak dipanen pada akumulasi satuan panas $1851.4{ }^{\circ} \mathrm{Cd}$ dengan umur panen 105 HST.

\section{DAFTAR PUSTAKA}

Adisarwanto, T, A, A., Rahmianna, Suhartina. 1993. Budidaya kacang tanah, hal. 89102. Dalam: Balai Penelitian Tanaman Pangan Malang (Ed.). Monograf Balittan Malang (ID): Kacang Tanah. Balai Penelitian Tanaman Pangan Malang, Malang.

BPS. 2013. Statistik Indonesia 2013. Badan Pusat Statistik.

[BALITKABI] Balai Penelitian Tanaman Aneka Kacang dan Umbi. 2013. Teknologi Produksi Kacang Tanah [Internet]. [diunduh 2013 Des 10]. Tersedia pada: http://www.balitkabi.litbang.deptan. go.id/.

[DEPTAN] Departemen Pertanian Republik Indonesia. 2011. Pedoman Umum Gerakan Penganekaragaman Konsumsi Pangan 2011. Jakarta (ID): Badan Ketahanan Pangan Deptan.

Direktorat Jenderal Tanaman Pangan. 2013. Pedoman Teknis Pengelolaan Produksi Kacang Tanah, Kacang Hijau, dan Aneka Kacang 2013[Internet]. [diunduh 2014 Jun 29]. Tersedia pada: http://tanamanpangan.deptan.go.id/.
Ketring, D, L., Reid, J, L. 1995. Peanut growth and development. Di dalam: Mellouk, H.A., Shokes, F.M., eds. Peanut Health Management. Minnesota: APS Press.

Kuntyastuti, H. 1993. Penggunaan metode satuan panas untuk menentukan umur panen kacang hijau [tesis]. Bogor (ID): Institut Pertanian Bogor.

Leong, S, K., Ong, C, K. 1983. The influence of temperature and soil water deficit on the development and morphology of groundnut (Arachis hypogaea). J. Expl. Bot. 34(148):1551-1561.

Marzuki, A, R. 2009. Bertanam Kacang Tanah. Jakarta (ID): Penebar Swadaya.

Pitojo, S. 2005. Benih Kacang Tanah. Yogyakarta (ID): Kanisius.

Purnamawati, H. 2012. Analisis potensi hasil kacang tanah dalam kaitan dengan kapasitas dan aktifitas source dan sink [disertasi]. Bogor (ID): Institut Pertanian Bogor.

Purwono, Purnamawati, H. 2007. Budi daya 8 Jenis Tanaman Pangan Unggul. Bogor (ID): Penebar Swadaya.

Santoso, Y.S. 2013. Penentuan umur panen tiga varietas kacang tanah (Arachis hypogaea L.) berdasarkan akumulasi satuan panas [skripsi]. Bogor (ID): Institut Pertanian Bogor.

Wang, Jen-Hu. 1960. Artique of the heat unit approach to plant response studies. Ecology 41 (4):785-790.

Widjanarko, A, A., Taufiq, A, A., Rahmianna. 2009. Pengaturan Jarak Tanam Ubikayu dan Kacang Tanah untuk Meningkatkan Indeks Pertanaman di Lahan Kering Masam Banjarnegara [Internet]. [diunduh 2013 Desember 04]. Tersedia pada : http://www.balitkabi.litbang.deptan.go.id. 
Bul. Agrohorti 4 (1) : 20 - 28 (2016)

Yudiwanti, Sudarsono, Purnamawati, H., Yusnita, Hapsoro, D., Hemon, A, F., Soenarsih, S. 2008. Perkembangan pemuliaan kacang tanah di Institut Pertanian Bogor. Inovasi Teknologi Kacang-kacangan dan Umbiumbian. Mendukung Kemandirian Pangan dan Kecukupoan Energi. Di dalam: [Balittan] Badan Litbang Pertanian. Prosiding Seminar Hasil Penelitian Tanaman Kacang-kacangan dan Umbiumbian; 2007 November 19; Malang, Indonesia. Malang (ID): Badan Litbang Pertanian. hlm 152-161. 